\title{
How Can Be Academic Talent Measured During Higher Education Studies? - An Exploratory Study
}

\author{
János Szabó \\ ${ }^{1}$ Institute of Psychology, University of Pécs, Hungary \\ Correspondence: János Szabó, Institute of Psychology, University of Pécs, Pécs, Hungary. E-mail: \\ szabo.janos@pte.hu
}

Received: September 29, 2019

Accepted: October 31, 2019 Online Published: November 11, 2019

doi:10.5539/hes.v9n4p200

URL: https://doi.org/10.5539/hes.v9n4p200

\begin{abstract}
Many articles claim that talent management is a very important aspect of higher education. Despite of this, the studies, which investigate this topic empirically, are very rare. The Hungarian higher education talent management focuses mainly on academic-, scientific aspect of talent. So, the main purpose of talent-management is the academic reinforcement, namely, growing up a new generation of scientist/university teachers. The talent management in higher education can be imagined as a bridge between formal school studies and scientific career. In this study, I search answer for the (research) question: how should academic talent be measured during higher education studies? Moreover, does it have any sense to identify the academic talents during even their higher education studies? The research is based on opinion of 170 university teachers who supervised talented students during a young-researcher competition. The method was questionnaire-method. The questions gathered round two main topics: (1) identifying of talented students and cooperation with talented students; (2) own career of supervisor university teachers. The results had been analyzed with descriptive statistics which show the mostly chosen talent-identifying methods and features of talented students. The open-ended questions had been content-analyzed. The data of university-teacher's career had been analyzed with mathematical statistical tests (ANOVAs, Two-sample T tests, correlations) where the dependent variable was the number of publication (as indicator of the scientific performance). The results may suggest conceptions for talent-programs (honor programs) based on academic talent; for doctoral schools, and for any other institutes who works with career entrant scientist. The scientific reinforcement would be more effective if scientific programs/scholarships/PhD-programs used professional methods during selection process, instead of subjective choices, based on CV and motivation letter.
\end{abstract}

Keywords: academic talent, gifted students, higher education, honor-students, talent management

\section{Introduction}

Comparing with the gifted education during primary and secondary studies (nurturing and developing intellectually emerging children), the higher-education talent management is an under-investigated area. A lot of study approaches this topic from HR-aspect (Neri\& Wilkins, 2019; Gandy, Harrison\& Gold, 2018; Boichenko, 2015). Among the studies written about talented students, just a few investigate the talented students with empirical methods (Cognard-Black \&Spisak, 2019).

There are studies that explore scientists' personalities and cognition. Examples of these studies address the unique personality and individual traits of scientists (Simonton, 2004a; Feist 2006; Helmreich, Spence, Beane, Lucker, \& Matthews, 1980). The psychology of science, a sub-area of psychology, deals with the mental background of the motivational, cognitive, and creative factors at scientific activities (Feist, 2006). This space between secondary-school gifted education and starting one's academic/scientific career (working as a scientist) is what is termed higher education talent management, in Hungary. So, the talent management in higher education can be imagined as a bridge between formal school studies and scientific career. Many scientists have already been involved in scientific research during their university studies (Feist, 2006). However, in Hungary, only few higher education institutes have professional and formal talent management system. Fortunately, some programs and projects have been founded which try to connect the two areas (higher-, and secondary education). These programs filter out gifted students in the secondary schools, and then help them get involved in an appropriate gifted education form or format (Balogh, 2012). This is why this topic is an interesting one and a 
new potential area to investigate. So, investigating this topic means filling the gap between the literature of psychology of science, and giftedness at the primary and secondary schools, because it is not sure that the students with best high school GPA will be the most successful scientists.

Another argument of higher-education talent development must be mentioned. Higher education has become a standardized, structured approach of mass education in many countries over the past few decades. This is a shift from what the university was for centuries; a form of gifted education in and of itself (Balogh, 2012). Therefore, talented students must be identified in this mass-education approach and provide them appropriate services. We must pay critical attention to prevent gifted secondary school students from dropping out of their studies, and at the same time, locate new potential scientists among the university students.

There are studies which used psychological questionnaires or scales to measure talented - such students who are involved into honor/talent programs - students in higher education. These studies usually found differences between talented and non-talented students. For example: Talented students are more opened to the experiences and more conscientious than their non talented peers (Long \& Lange, 2002). An investigation used BIG5 questionnaire which proved that talented students are more conscientious, open, emotionally instable, and introverted (Achtenberg, 2005; Cross, 2018). Besides psychological features, the GPA, learning strategy (Cuevas, Schreiner, Kim\& Bloom, 2017), and behavioral features are also used methods at investigation of this topic. The GPA is higher at honor students than non honor mates (Cognard-Black, \& Spisak, 2019), but this does not prove to be true in every case (Shushok, 2006). The most investigated features connect to the living on the campus, free-time, connect with the faculty and faculty member, and participating in activities. The honor students train and sleep more, than their non-honor mates; they consult more with their teachers; they participate more in religious activities, in charity work, and community service (Cognard-Black \& Spisak, 2019).

The purpose of this study is providing information only about academic/scientific talent, namely: about such students who are interested in conducting researches and orient toward the scientific career. The Hungarian higher education talent management system is based on nurturing of the new generation of scientist (read below). So the results could be helpful at applying process of talent management programs (even honor programs) or even at PhD-applying process.

\subsection{Scientific Creativity and the Attributes of Scientists}

The main goal of Hungarian talent development is encouraging the life of the mind, involving the young professional in the academic guild, and fostering the next generation of scientists and academics. University professors strive to develop scientific creativity in diverse ways. But what exactly is scientific creativity? And what factors or variables comprise it? In this section, we will survey what this notion means and which factors were found to be important and relevant in earlier research studies.

Scientific creativity means the totality of thoughts and behaviors necessary to advance discipline-specific knowledge. As science progresses there needs to be validation from the professional society and through the rigorous process of academic research (theoretical substantiating, hypothesis construction, researching, publication, lecture) (Feist, 2006). This aspect of creativity manifests in the connection of the person, relationships, and their diverse environments. Namely, the researcher investigates and tests and hypothesizes phenomena and relationships of the world. The base of scientific creativity is in many instances an intuitive thought, a supposition, or a moment of coincidence found in unexpected nexuses. It is necessary to mention that this kind of creativity nowadays has become a teamwork approach rather than an individual activity (Feist, 2006).

Feist (2006) has described this construct of scientific creativity, and he has also collected and organized the correlating attributes of the productive scientific career:

- Cognitive traits: open-mindedness, patience, flexibility, psychological mindedness

- Motivation traits: ambition, drive, intrinsic motivation

- Social traits: dominance, arrogance, hostility, introversion, self-confidence.

A scientific career is, partially, measured by performance. This performance revolves around contribution to the scientific community, often through publications. The number of published works correlates with hard work, with competence, with one's professional background, and with a sense of competition. However, if we look at the citation rate, then only hard work and professional background correlate with this rate (Simonton, 2004b).

Finally, we must speak about the measurement of the scientific creativity. This issue can be approached even from four aspects: from the aspect of the scientific product (the article), from the aspect of the scientists' 
personalities, from the aspects of creative process, and finally from the aspect of the situation (Stumpf, 1995). The product can be measured on the one hand by the SCI (Science Citation Index - How many times was the article cited). The other way is rating by experts. This measures the quality by similar viewpoints, like novelty, resolution (utility at the problems in the realty), etc. This way is used at the evaluating of the OTDK-works (see next chapter). The creative process means those mental steps and activities which are necessary to carry out a research. For example: extended effort, verification, elaboration, etc. These processes can be inspected by introspective reports and they are very variable: which these steps are, which the order of these steps is, they vary at every research and every science area. The creative situation is the summary of those factors which contribute to the scientific creativity. A lot of factors are included into this: the spirit of the times, politicalcultural- historical- ideological background, the needs of the society, etc. And finally, from the aspect of the researchers' personalities what is described in the earlier chapters. This part contains the personality traits and cognitive factors which were mentioned above (Stumpf, 1995). And this is the way how I have investigated the talent-factors in this study.

\subsection{Higher-education Talent Management around the World}

The majority of the conducted empirical studies was conducted in the U.S.A, where $300000-400000$ students participate in honor programs (Cognard-Black \& Spisak, 2019). These honor programs means the talent management during higher-education studies. Although, the conceptions of these programs are different in institutes, universities; there are some common features. For example: the "talented" refers to the academically talented undergraduate students (Cognard-Black \& Spisak, 2019). So, when we read the literaute of higher-education talent management, we meet mainly with "honor student" term, instead of talented student. Hence, the honor program is an American conception, it would be not appropriate to use at the case of Hungarian conceptions.

In the aspect of talent-management programs, the European universities are underrepresented, compared to American ones. Much less university has talent program in Europe, and the majority of these are found in the Netherlands (Wolfensberger, 2015). Hence, empirical researches about talented students in higher education are very rare in Europe. The few examples are mainly originated also from the Netherlands (Scager et al., 2012; Hammer, 2015). So, conducting an empirical research, involving talented university students, is a fairly new approach.

The purpose of this study is not comparing the Hungarian higher education talent management to ones of another nation. Although, it is essential to clarify what "talent" means in this context. The Hungarian talent management conceptions - how it is elaborated below - are based on the scientific reinforcement (fostering a new generation of scientists). So, they are focusing rather on the scientific activities (e.g. conducting own researches, publishing into scientific journals) and scientific career, than on professional career and labour market.

\subsection{Higher-education Talent Development Forms in Hungary}

This study has been conducted in the frame of the Hungarian talent development system where we refer to "talented students" as persons who take part in additional opportunities besides the obligatory studies (by joining a szakkollégium or a research group or a talent program; managing their own research project; writing a TDK-work). The "talent management" programs in Hungarian higher education refers to the system in a university which helps students become involved in scientific research, to present their results in scientific conferences, or to publish their papers in peer-reviewed journals. The main role in higher education talent management belongs to the supervising university professors who teach the talented, interested students how to conduct scientific research and participate in the professional guild. There are also administrators who help the talented students to find scholarships, conferences, and research supplement funding and opportunities. In Hungary, there is a statute in the constitution (2005. CXXXIX. statute 66. §), according to this regulation, every higher education institute (all colleges and universities) has to take care about its talented students in a talent-management form (Bodnár, Takács, \& Balogh, 2011).

Wolfensberger (2015) introduces 11 countries detailed: with describing the higher-education institutes, the education system, the educational forms and these are supplemented with empirical data. Similarly to the introduced countries, there are also some universities in Hungary, where complex honor-education forms are used which worth to mention. The other reason of introducing the Hungarian forms is that: I have collected the data here.

In Hungary, there are more conceptions which are available for the talented students who are interested in the scientific career. A lot of colleges and universities have own local conceptions, for example: research-seminars, lecture-series, vocational trainings, workshops, learning-groups, even summer-camps which are important parts 
of the university-life. The majority of them involve just few students in favor of the effective work/learning. The base of these conceptions is mainly the initiation of a teacher or the enthusiasm of students. In these forms, the informal, collegial, or even friendly relation is very important in favor of the effective cooperation among the students and the teachers. They mainly work just inside the walls of a department/an institute, they are less structural and more informal, so it is harder to investigate them empirically, than the standard national talent developmental conceptions (OTDK, Champaign of Szakkollégiums, global-university talent programs) which works similarly around the universities of Hungary. But they are important part of the scientific talent management, because in the frame of these groups (seminars, workshops, etc.), the students can learn easier the bases of the scientific research's methods, owing to the little-group-modality, the low headcount, the informal relations. Hence, the higher-education became mass-education, these forms have been crowded out from official study-plan (Hrubos, 1999).

Beside of these local low-headcounter-forms, there are more central/national conceptions (expended into the level of whole nation/university) which help for the students to start and to continue their scientific career. There are projects which overarch to secondary schools (for example: Talent-passport Program, Szinapszis mentor-program, Talent-bridges Program), as a bridge between gifted education and higher education. The goal of these programs is to reach the inquiring secondary school students: They continue supplementing the talent-management process and help the students to fit in the new university-atmosphere. These conceptions mainly work in the frames of mentor-tutor system.

So, the students, who were investigated in this study, were "scientifically" talented according to the conception of Hungarian higher education talent management system. It means that, in the Hungarian higher education talent management, a "talented" student means a potential scientist/university teacher/faculty member. That is why, the main criteria during $\mathrm{PhD}$ applying process is a student's earlier research activities (what he/she performed during his/her higher education studies).

\subsubsection{The Two Main Form of Hungarian Talent Management in Higher Education}

One of the main talent management forms is the TDK-system. "TDK" and "OTDK" terms mean Scientific Conference for Students and National Scientific Conference for Students. The OTDK (national version) is organized in every second year. It is a national research competition among the most talented university students in Hungary. TDK (local version) is organized every half year. The university-students can qualify to the OTDK by their TDK-results. There are 13 sections according to 13 science domains (e.g.: social-sciences, chemistry, medicine, biology, humanities, law, etc.). Every section is split into c.a. 10-30 sub-sections which are based on a narrow field or a special topic (e.g.: personality psychology, developmental psychology, educational psychology, criminal psychology, etc.). At the end of the conference, the best researches (and the students who conducted them) are awarded with first/second/third place, or special prize. The participation and the award in OTDK act positively at the $\mathrm{PhD}$ applying process.

The other main talent management form is the Movement of Szakkollégium. This is a group-based talent management conception. The szakkollégiums work in the frame of a university (like guilds). The organizational structure of szakkollégiums bases on democracy, the members continuously form that. That is the reason, why the rules, programs, number of members, focus of development, and requirements of szakkollégiums in different universities can be very diverse. Just the three pillars are common: living together; forming a community; endeavor toward mastery. This conception is similar to "community of practice" form in the U.S.A. (Hua, Shore, \& Makarova, 2012). The accredited szakkollégiums form into a network that is supervised by the committee of Movement of szakkollégium. The delegates of szakkollégiums ordinary meet to debate about the issues pertained to the movement of szakkollégium. Any szakkollégium from any university can join to this network (and become accredited szakkollégium), if it succeed the requirements that are based on the above mentioned three pillar.

Beside the two national talent management form (OTDK; Szakkollégium), there are complex higher-education talent developmental programs in the universities. These mean excellent opportunity for students who want to join to the scientific work, to supplement their studies, and to get better in their profession/science-area. In these forms, earlier unknown competences of the students may appear during the talent supplement process: strong and stable vocational identity; motivation for the research-work; but interest about earlier-far-believed science areas also can be formed. Some of them are similar to honor programs.

\section{Method}

The source of data was a questionnaire with 23 questions (open-ended questions; multiple choices questions; yes/no questions). The questions gathered round two main topics: (1) identifying of talented students and cooperation with talented students; (2) own career of supervisor university teachers. To make the data more 
interpretable, I attach the questionnaire as Appendix 1.

\subsection{Sample}

The sample consists of faculty members: such faculty members who were supervisors of academically talented students (students who qualified to OTDK 2017 competition). The university teachers (faculty members) were recruited by the database of OTDK 2017. This database contains: name of the students who earned first/second/third places or special-prize; title of his/her research-work (OTDK-work); his/her affiliation (university); name/names of his/her supervisor(s). The only one condition of adding a university-teacher to the recruitment database was: being in the following position: professor, associate professor, assistant professor, research-fellow. 750 university teachers were added to the recruitment-database. 722 email addresses of them were found on the webpage of their universities. So, the questionnaire has been sent to almost 722 professors (owing to several "address not found" error messages). 170 answers have come in $(\mathrm{N}=170)$. The participants came from every science-domain how Figure 1 shows.

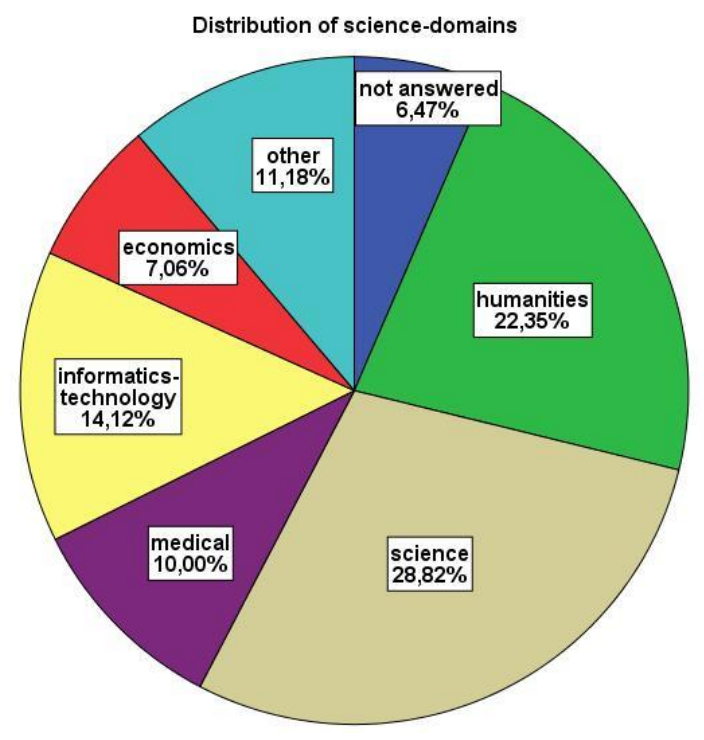

Figure 1. Distribution of science-domains

6 persons from military +6 persons from law +7 persons from agricultural studies had been contracted into "other" category. Figure 2 shows the distribution of the positions according to the answer-givers.

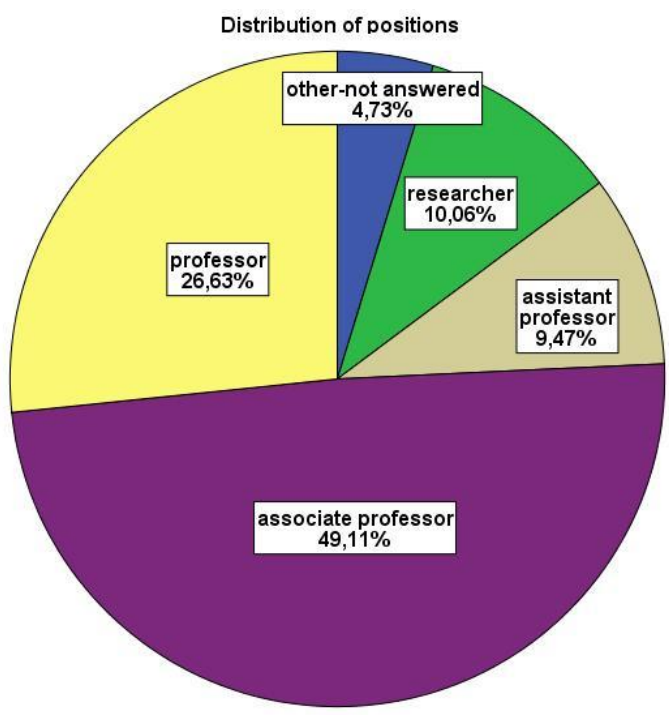

Figure 2. Distribution of positions 


\section{Results}

Hence, the main purpose of this study was exploration of university-teachers' opinions, the most of questions had been analyzed with descriptive statistic (ranking the mostly chosen answers, frequencies of answers, distributions of available options).

$74,9 \%$ of participants declared that "Yes, it can be predicted about a student during his/her higher education studies whether he/she becomes a scientist/a university teacher."

$81,3 \%$ of participants declared that "Yes, it has sense/relevance to care about the issue: predicting, whether somebody would be a good scientist or not."

The mostly marked options to the question: "If yes; what are the indicators during undergraduate studies that somebody prepares to scientific career?" were:

- He/she puts the balance at his/her essays/papers rather on the quality, than the length of the text. $-75.5 \%$

- In his/her questions, comments and papers, he/she refers often to other learning materials and other science domains. $-60.9 \%$

- He/she is interested in scholarships and study tours abroad. $-49.7 \%$

The mostly marked option to the question: "Which methods/information/data can be effective to identify academic undergraduate talents?" was:

Test-tasks, based on practical problems $-52.4 \%$ (The only one above $50 \%$ )

$72.9 \%$ had exemplar person.

$64.9 \%$ got into his/her actual job (position at university) by invitation.

$50.9 \%$ of participants must motivate his/her students to cut in a TDK-research, a TDK work.

$67.9 \%$ of the participants usually submit his/her papers to publish, despite of the non-consistent results.

Finally, I present the data of scale type variables:

Number of publications (“How many scientific papers have you published till now?"): Mean: 100.83; SD: 72.31

Number of rejected publications ("How many scientific articles of yours have been rejected (not ever published) after being submitted to a peer-reviewed journal?”): Mean: 11.55; SD: 17.44

Number of rejected scholarship-opportunity/application/financial research support ("How many of your research grant applications have been rejected/not funded?"): Mean: 5.61; SD: 5.15

The open-ended questions had been content-analyzed. At first, I analyzed the open-ended part of the indicators of talent. There were 89 answers, from which 81 were adequate. I split the answers into three main categories:

(1) mentioned only intrapersonal features - ,intrapersonal” category $-49.38 \%$

example: ,,creativity, susceptibility toward new things, consistency, seriousness”

(2) mentioned only behavioral features - ,behavioral” category $-28.40 \%$

example: ", he/she makes contact with the relevant teacher"

(3) mentioned both intrapersonal and behavioral features - ,blended" category - $22.22 \%$

example: „He/she cuts in research-work, proactive, reliable, persistent.”

not categorized (not involved) answers: every answer, which does not mention a concrete feature:not-answers, theoretical-philosophical thoughts about talent identification, reflections/critics about the questionnaire ( 8 answers).

example: ,These attributes describe every intelligent student, but, according to my opinion, they don't describe truly the character of a scientist.

The distribution of these categories is represented on Figure 3. 


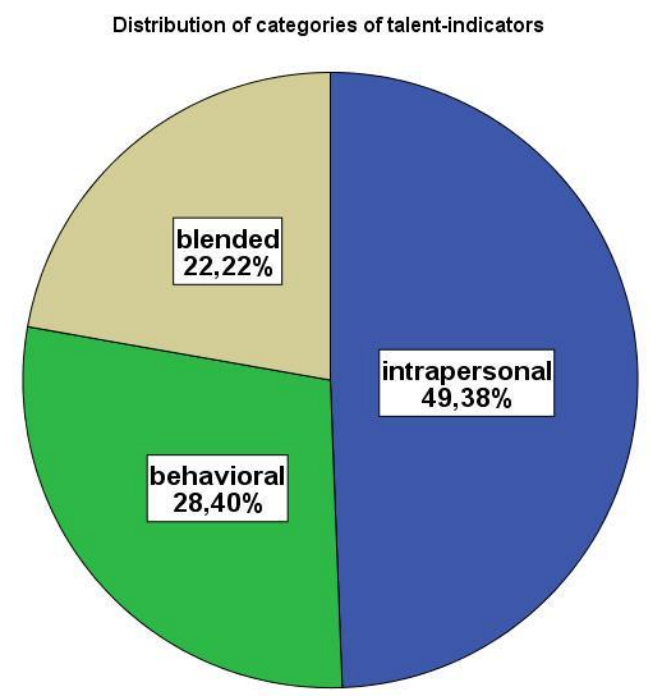

Figure 3. Distribution of categories about indicators of talent

Sub-categorizing "intrapersonal" category, I used a 66 items matrix. This matrix was used during an earlier similar study (Szabó, 2018). All of the elements of this matrix connect to "talent" notion. Table 1 contain the mostly written interpersonal attributes of a talented student.

Table 1. Mostly mentioned intrapersonal features

\begin{tabular}{ll}
\hline $\begin{array}{l}\text { Attributes from the 66 items matrix } \\
\text { (number of mention) }\end{array}$ & $\begin{array}{l}\text { "new” attributes; emerged during the research } \\
\text { (number of mention) }\end{array}$ \\
\hline $\begin{array}{l}\text { Curiosity, interest (17) } \\
\text { Self-dependence (10) }\end{array}$ & $\begin{array}{l}\text { Exactitude (5) } \\
\text { Persistence, engagement (10) }\end{array}$ \\
Recognizing the coherency (6) & \\
Creativity (6) & \\
Ambition (5) & \\
Highlighting the mean (4) & \\
\hline
\end{tabular}

Note. Only the more than 3 times mentioned features)

*The "motivation" was split into "extrinsic" and "intrinsic" types in the 66 items matrix.

The sub-categorization of "behavioral" features had been managed by counting the mentioned features. The mostly mentioned behavioral features are the following (only the more than 3 times mentioned features):

- participating on TDK (9 times)

- quality of completed tasks (7 times)

- getting connected with a mentor-teacher (5 times)

- additional activities besides the curriculum (5 times)

Beside of the question about indicator of talent, I asked directly to the attributes of a talented student. The aim of question was to focus to the intrapersonal attributes. The base of categorization was the 66 items matrix which is mentioned above and the categorization happened the same way, as the case of the question about indicators (analyzed above). Table 2 show the results of this analysis. 
Table 2. Mostly mentioned intrapersonal features

\begin{tabular}{ll}
\hline $\begin{array}{l}\text { Attributes from the 66 items matrix } \\
\text { (number of mention) }\end{array}$ & $\begin{array}{l}\text { "new" attributes; emerged during the research } \\
\text { (number of mention) }\end{array}$ \\
\hline Self-dependence (51) & "motivated"* (25) \\
Curiosity, interest (48) & Creativity (18) \\
Diligence, practice (42) & Exactitude (15) \\
Persistence, engagement (24) & Humbleness toward science (12) \\
Intelligence (10) & Tolerance of stress and high standards (10) \\
Ambition (10) & Critical approach (8) \\
Open-mindedness (9) & Reliability (6) \\
Base of knowledge (9) & Enthusiasm (6) \\
Social Competence (8) & Analytical thinking (5) \\
Logical thinking (7) & Proactivity (4) \\
Manifestation of ideas (4) & Problem solving skills (4) \\
\hline
\end{tabular}

Note. Only the more than 3 times mentioned features)

*The "motivation" was split into "extrinsic" and "intrinsic" types in the 66 items matrix.

The following question, which was content analyzed, referred to the motivations of academic career. The question tried to explore why someone wants to be a university teacher/scientist. Table 3 introduces the results with examples.

Table 3. Motivations of academic career

\begin{tabular}{|c|c|c|}
\hline Category & Number of mention & Examples \\
\hline Epistemic needs & 49 & $\begin{array}{l}\text { expansion of knowledge, curiosity, interesting, } \\
\text { searching answers, discovery etc. }\end{array}$ \\
\hline education & 38 & $\begin{array}{l}\text { every motivation connected to education: teaching, } \\
\text { spreading knowledge, upbringing the generation of future, etc. }\end{array}$ \\
\hline freedom & 19 & $\begin{array}{l}\text { freedom of acting, flexible working hours, flexibility, } \\
\text { low fixity, weak hierarchy }\end{array}$ \\
\hline research & 14 & the joy of the research-activity in itself \\
\hline social environment & 11 & colleagues, opportunity of teamwork, intellectual environment \\
\hline exemplar person & 9 & one or more exemplar-person (a teacher, a parent) \\
\hline variedness & 7 & mentioned „various” term, e.g.: various activities \\
\hline challenge & 7 & intellectual or professional challenge \\
\hline prestige & 4 & mentioned ,prestige" \\
\hline engagement & 4 & engagement into a topic/a science-domain/a profession \\
\hline
\end{tabular}

Note. Only the more than 3 times mentioned features)

Beside the "why wants somebody become a university-teacher" question, it was also asked when the participants decided to become a university teacher. Distribution of the career choosing-time question is represented on Figure 4. 


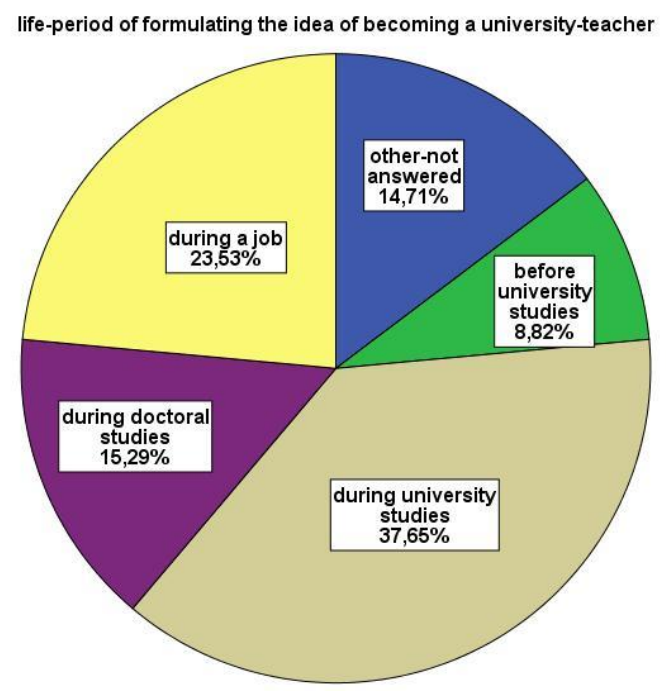

Figure 4. Distribution of life-period during when it formulated the idea of academic career

Figure 4 shows that the most participants chose his/her career during his/her higher education studies. By the result of an ANOVA, there are no significant difference among the groups based on the decision of becoming a university-teacher (before my university studies, during my university studies, etc.) in the aspect of number of publications $(\mathrm{F}=0.305 ; \mathrm{df}=162 ; \mathrm{p}>0.05)$.

By the result of a T-test, there is no significant difference between the participants, who had exemplar-person, and the participants, who had not, in the aspect of number of publications ( $\mathrm{T}=-0.664 ; \mathrm{df}=161 ; \mathrm{p}>0.05)$.

There is no significant correlation between the published papers and the rejected papers. These results induct that the "law of big numbers" is not valid at publishing.

There was a question about the two main tasks of university teachers: "Which is important for you: teaching or researching?" Teaching option was chosen by $11.2 \%$ of the participants. Researching option: $26,5 \%$; "both are equally important": $60 \%$. 2.4\% cannot decide it. By the result of an ANOVA, there is at least one significant difference among these groups in the aspect of number of publications $(\mathrm{F}=2.894 ; \mathrm{df}=162 ; \mathrm{p}<0.05)$. By a Sidak post hoc test, it emerged that the "teaching" group publishes significantly less than the "equally" group. Although, this result is obviously, and there was just one significant difference, it is interesting that the "both" group has the most publications. This is proven by Figure 5 .

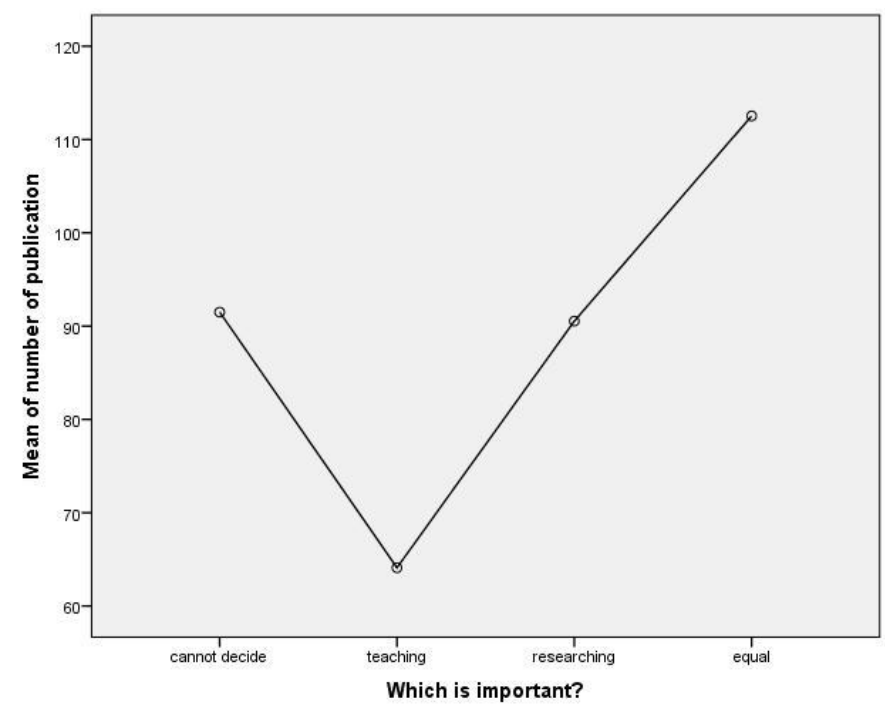

Figure 5. Number of publications of groups based on task-importance 
67.9\% of participants submit their results to a journal, despite of the not consistent results with the expectations/hypotheses. $14.9 \%$ does not submit they get non-expected result. $17.3 \%$ claimed that it has never happened yet. By the result of an ANOVA, there are no significant difference among these groups in the aspect of number of publications $(\mathrm{F}=0.119 ; \mathrm{df}=162 ; \mathrm{p}>0.05)$.

\section{Discussion}

Circle three-quarter of participants think that the academic talent management and talent identification is a relevant topic which has sense.

The university-teachers, who prepared earlier to the scientific career, have not significantly more publication than the ones, who decided it later. Although, $44 \%$ of participants decided during their higher education studies or earlier that they want to be a university teacher. This also means that there is relevance to care about the academic talent management during higher education studies. This tendency appeared at the questions about exemplar-persons: There was no significant difference between the two groups (yes or no), but the majority of participants had exemplar person during his/her studies.

Analyzing the academic performance (number of publication), only two results emerged in the aspect of the differences among groups: (1) the more time spends somebody in the academic career, the more publication he/she has; (2) who thinks more important teaching, he/she publishes less than ones who think more important the research or think equally important the two main activities of a university teachers. The other test did not establish differences. So, it is the same whether a university teacher has exemplar person or not; whether he/she engages to scientific career early or late; whether he/she publishes non-expected result or not. It is the same if somebody tries to publish at a lot of time because it has emerged that the "law of big numbers" is not valid at publishing (there is no correlation between number of published and rejected articles).

The main limitation of this study: the equality sign between the academic performance and the number of publications. It was the most optimal choice, because the questionnaire had to be short owing to the very few time of university-teachers. Although, unfortunately, there are scholarships/applications/financial research-supports at which the decision-criteria is based on the number of publications.

Another limitation of this study: it cares about just the intrapersonal features. The most cited talent models refer to the social environment, as a precondition of talent-manifestation. This feature has also important role in the case of academic/scientific talent. Although, during young-adulthood age/higher education studies, the responsibility mainly is on the supervisor-professors, who get connected directly with talented student, instead of parents and peers. Of course, this does not mean that the early environment has unimportant role, because there are scientists who chose the academic career owing to the knowledge-based values during their childhood. Further researches about social environment would be useful at uncovering the scientists' mind. Opportunity is also an important, external factor at manifestation of talent. Although, participating in talent management conceptions and beginning own researches during higher education studies are open for every students; there are students who have not any time to care with researches, despite of he/she would be interested in. But the practical experience in Hungary shows that the studens are in majority, who would have free time to involving talent management, even so they are not interested in.

Hence, the mostly chosen option had been the "Test-tasks, based on practical problems" at the question about identifying methods (the only one above 50\%), a future direction can be going further toward special-science domains. This way of identifying is not unique in the higher education: in the Aurora-project, the applicant-students had to fill out also part-test based on practical problems (Sternberg, 2010). The motivations of scientific career (being a university teacher) can be a base for talent management programs that want to recruit academically talented students. The list of attributes of talented students can be also a recruitment base. To measure these attributes with psychological questionnaires is complicated, how an earlier investigation proved (Szabó, in press). The participants declared: the best indicators are the quality of a student's papers and the interdisciplinary, holistic viewpoint.

The results may suggest conceptions for talent-programs (honor programs) based on academic talent; for doctoral schools, and for any other institutes who works with career entrant scientist. The scientific reinforcement would be more effective if scientific programs/scholarships/PhD-programs used professional methods during selection process, instead of subjective choices, based on CV and motivation letter.

The summarization of this study: the fate of an academic talent is absolutely not decided during higher education studies, but it is proved that a lot of scientific career start during higher education studies. 


\section{References}

Achterberg, C. (2005). What is an honors student?. Journal of the National Collegiate Honors Council, 6(1), 75-83.

Balogh, L. (2012). Komplex tehetségfejlesztő programok. Didakt kiadó, Hajdúböszörmény.

Boichenko, M. (2015). Talent Management Programmes at British, American and Canadian Universities: Comparative Study. Comparative Professional Pedagogy, 5(4), 68-72. https://doi.org/10.1515/rpp-2015-0068

Bodnár, G., Takács, I., \& Balogh, Á. (2011). Tehetségmenedzsment a felsőoktatásban. Magyar Tehetségsegítő Szervezetek Szövetsége, Budapest.

Cognard-Black, A. J., \& Spisak, A. L. (2019). Creating a Profile of an Honors Student: A Comparison of Honors and Non-Honors Students at Public Research Universities in the United States. Journal of the National Collegiate Honors Council, 20(1), 123-157.

Cross, T. L., Cross, J. R., Mammadov, S., Ward, T. J., Neumeister, K. S., \& Andersen, L. (2018). Psychological heterogeneity among honors college students. Journal for the Education of the Gifted, 41(3), $242-72$. https://doi.org/10.1177/0162353218781754

Cuevas, A., Schreiner, L. A., Kim, Y., \& Bloom, J. (2017). Honors student thriving: A model of academic, psychological, and social wellbeing. Journal of the National Collegiate Honors Council, 18(2), 79-119.

Feist, G. J. (2006). The psychology of science and the origins of the scientific mind. New Haven, CT: Yale University Press.

Gandy, R., Harrison, P. \& Gold, J. (2018). Talent Management in Higher Education: Is Turnover Relevant?. European Journal of Training and Development, 42(9), 597-610. https://doi.org/10.1108/EJTD-11-2017-0099

Hammer, M. H. (2015). Towards a Methodology to Identify a Talent by Using Psychological Cognitive Prototyping. Practice and Theory in Systems of Education, 10(4), 397-409. https://doi.org/10.1515/ptse-2015-0038

Helmreich, R. L., Spence, J. T., Beane, W. E., Lucker, G. W., \& Matthews, K. A. (1980). Making it in academic psychology: Demographic and personality correlates of attainment. Journal of Personality and Social Psychology, 39, 896-908. http://dx.doi.org/10.1037/0022-3514.39.5.896

Hrubos I. (1999). A felsőoktatás dilemmái a tömegessé válás korszakában. Oktatáskutató Intézet, Budapest

Hua, O., Shore, B. M., \& Makarova, E. (2014). Inquiry-based instruction within a community of practice for gifted - ADHD college students. Gifted Education International, 30(1), 74-86. http://dx.doi.org/10.1177/0261429412447709

Long, E. C. J., \& Lange, S. (2002). An exploratory study: A comparison of honors \& non-honors students. The National Honors Report, 23(1), 20-30.

Neri, S., \& Wilkins, S. (2019). Talent Management in Transnational Higher Education: Strategies for Managing Academic Staff at International Branch Campuses. Journal of Higher Education Policy and Management, 41(1), 52-69. https://doi.org/10.1080/1360080X.2018.1522713

Scager, K., Akkerman, S. F., Keesen, F., Mainhard, M. T., Pilot, A., \& Wubbels, T. (2012). Do honors students have more potential for excellence in their professional lives?. Higher Education, 64, 19-39. https://doi.org/10.1007/s10734-011-9478-z

Shushok, F. (2006). Student outcomes and honors programs: A longitudinal study of 172 honors students 2000-2004. Journal of the National Collegiate Honors Council, 7(2), 85-96.

Simonton, D. K. (2004a). Creativity in science: Chance, logic, genius, and Zeitgeist. Cambridge University Press, Cambridge, UK. https://doi.org/10.1017/CBO9781139165358

Simonton, D. K. (2004b). Creativity as a Constrained Stochastic Process. In: R. J. Sternberg, E. R. Grigorenko \& J. L. Singer (Ed.), Creativity From Potential to Realization. (pp. 83-102) American Psychological Association. Washington, DC. https://doi.org/10.1037/10692-006

Sternberg, R. J. (2010). Assessment of gifted students for identification purposes: New techniques for a new millennium. Learning and Individual Differences, 20, 327-336. https://doi.org/10.1016/j.lindif.2009.08.003 
Stumpf, H. (1995). Scientific Creativity: A Short Overview. Educational Psychology Review, 7(3), 225-241. https://doi.org/10.1007/BF02213372

Szabó J. (2018). A tudományos tehetség hat legfontosabb összetevője az egyetemi oktatók szempontjából. In: I. Koncz \& I. Szova (Ed.), A 15 éves PEME XVI. PhD - Konferenciájának elöadásai. (pp. 277-286) Professzorok az Európai Magyarországért Egyesület, Budapest.

Wolfensberger, M. (2015). Talent development in European Higher Education. SpringerOpen, Heidelberg. https://doi.org/10.1007/978-3-319-12919-8

\section{Appendix A}

The used questionnaire during the study (English translation)

Science-domain:

Can you/we identify during undergraduate study, which student will be a good scientist?

Yes

No

I cannot decide it.

Does it make sense to identify scientifically talented students during undergraduate studies?

Yes

No

I cannot decide it.

If yes; from when is it worthwhile to deal with this question?

$1-2-3-4-5-6-7$

1 - from the beginning of studies

7 - at the end of the studies

If yes; what are the signs during undergraduate studies that predict whether a student would be a successful researcher?

Choose from the options below, or write your own option/opinion/observation

$\mathrm{He} / \mathrm{she}$ visits regularly also lectures, not only obligatory seminars.

$\mathrm{He} / \mathrm{she}$ asks often in class.

$\mathrm{He} /$ she is simply very smart.

$\mathrm{He} / \mathrm{she}$ has creative ideas.

$\mathrm{He} / \mathrm{she}$ thinks like a scientist.

$\mathrm{He} / \mathrm{she}$ is passionate about science.

$\mathrm{He} / \mathrm{she}$ is curious and asks insightful and important questions.

$\mathrm{He} / \mathrm{she}$ knows the literature/research well.

$\mathrm{He} /$ she performs exceedingly at tests and exams.

His/her papers/essays are sententious and concise rather than long.

$\mathrm{He} / \mathrm{she}$ is popular among peers.

$\mathrm{He} / \mathrm{she}$ regularly takes part in university-programs (cultural, sport, community, etc.) and he/she utilizes the opportunities of university.

$\mathrm{He} /$ she enquires about internships, study-tours, scholarships abroad.

His/her questions, comments, essays often pertain to other science-domain, to other topic.

After a failed exam, a negative critic, he/she works/learns more intensively and tries it harder again.

$\mathrm{He} / \mathrm{she}$ asks for help often.

Own option/opinion/observation: 
Which methods/information are the most effective at identifying the talented students (the potential scientists)?

IQ test

Grade-Point-Average (GPA) in the end of the first semester.

Making them write an essay about future-plans

Psychological questionnaires about motivation/curiosity

Making them solving practical problems in their chosen science-domain

Tasks specialized to their chosen science-domain

Questions about societal problems/dilemmas

Own option/opinion/observation:

How did you get into this position at your university/college?

I was invited.

I applied for this job.

Other:

At what age were you when you first thought you wanted to become a university teacher (professor)?

Already before university/college studies

During my university/college studies

During doctoral studies

After finishing the university, in a workplace

Other:

How many years have you worked as a university teacher (professor)? (summarizing the earlier years in another universities/colleges)

$0-5$ years

$6-10$ years

$11-15$ years

$16-20$ years

More than 20 years

What age do you think you were when you were your most productive? (giving with years)

What was your primarymotivation for why you wanted to become a university teacher (professor)?

Own option/opinion/observation:

Did you have ideals (Vorbilden/ a person who is similar or who has some attributes as your future-image)? Yes

No

How was your conceptions fix about the future plans after degree during university/college studies?

On a 1 to 7 scale, how much of a career plan did you have while you were still studying?

$1-2-3-4-5-6-7$

$1-\mathrm{I}$ had no any idea.

7 - I had absolute concrete plans

Which task/quest is more important for you? Teaching or research?

Teaching

Research

They are alike 
I cannot decide it

How many scientific papers have you published till now (involving every article, book chapter, monograph, etc)?

How many scientific articles of yours have been rejected (not ever published) after being submitted to a peer-reviewed journal?

How many research grant applications have you had?

How many of your research grant applications have been rejected/not funded?

If the results do not match with the predictions/hypotheses, do you submit the article to publish?

In generally, yes

In generally, no

This has not happened yet.

\section{Copyrights}

Copyright for this articleis retained by the author(s), with first publication rights granted to the journal.

This is an open-access article distributed under the terms and conditions of the CreativeCommons Attribution license (http://creativecommons.org/licenses/by/4.0/). 